\title{
REVIEW FACILITY DEVELOPMENT OF AIRCRAFT TIRE RETREADING IN INDONESIA
}

\author{
Freddy Franciscus* \\ Faculty of Aerospace Technology, Suryadarma University, Indonesia \\ ${ }^{*}$ Corresponding Author: freddyf60@rocketmail.com
}

\begin{abstract}
Aircraft tire retread is the process of retreading or reconditioning aircraft tires after being used several times for take-off and landing. Retreading an aircraft tire can be done many times, which is between 3-5 times depending on the level of wear of the tire layer. Data from INACA 'Indonesia AviationOutlook 2017' shows that the number of jet aircraft owned by Indonesian airlines for Wide Body is 23 aircraft and Narrow Body is 338 aircraft. Where the number of aircraft tyre in the Nose Landing Gear / NLG and Main Landing Gear / MLG Wide Body aircraft are 55 EA and 216 EA respectively, while for Narrow Body aircraft each is 352 EA and 1488 EA. There is a huge opportunity in the need for retreading aircraft tires owned by Indonesian airlines, which is around USD 20 million per year, with $10 \%$ growth per year, so the next 5 years will reach around USD 30 million. However, this opportunity cannot be taken by MRO Indonesia because MRO Indonesia does not have the ability to retread airplane tires. The cause of the inability to take up an aircraft tire retreading business opportunity is partly because there is no government policy support to encourage aircraft tire manufacturers to collaborate with Indonesian investors to build a tire retread facility, there is business competition with aircraft tire retreading in Malaysia and Thailand, businesses most only think solely of big profits, and the unattractive business climate in Indonesia such as complicated licensing, inefficient supply chains and incentives provided are less attractive.

The steps needed to capture the opportunity to retread aircraft tires are to carry out continuous campaigns and incorporate aircraft tire retread facilities development programs into the National Strategic Program and the Aerospace Industry Roadmap.
\end{abstract}

Keywords: Retread Aircraft Tire, MRO, Tire Retreading, Aerospace Industry Roadmap

\section{INTRODUCTION}

\subsection{Background}

Retread aircraft tire is the process of retreading airplane tires where the airplane tires are reconditioned after taking off and landing several times and wear and tear strength decreases. Vulcanizing work of aircraft tires can be done many times, which is between 3-5 times depending on the wear conditions that occur on aircraft tires[1].

From Table 1.1 Types of Aircraft Jet and Tires Belonging to Indonesian Airlines' Source INACA Aviation Outlook 2017 above[2], it appears that the number of tires in Nose Landing Gear / NLG and Main Landing Gear / MLG wide body aircraft / Wide Body (B777- 300 and A330-200 / 300) are 55 EA and 216 EA, respectively. Meanwhile for the number of tires in NLG and MLG narrow body aircraft / Narrow Body (B737-800 / 900 / MAX and A320-200) are $352 \mathrm{EA}$ and $1488 \mathrm{EA}$, respectively. From various trusted sources, it is said that the business opportunity for retread tires in Asia Pacific is promising with an average growth of $10 \%$ / year. Information submitted by one competent official officer from an MRO states that the need for a tire retread in one of the major airlines in Indonesia every year is around USD 12 Million and when combined with the needs of another airline's tire retread is around USD 20 Millions per year with growth of around 10\% / Year for the next 5 years [3][4][5]. The need to retread the tire is a very promising and very attractive opportunity to be able to held at Indonesia's MRO. Meanwhile there is a plan from Dunlop Aircraft Tires Ltd. from England to invest around USD 70 Millions, Table 1.2 
List of IAMSA's Members 2019 and Its Capability who will make cooperations with PT. Rubberman Indonesia [6][7].

\subsection{Formulation of The Problems}

From Table 1.2 'IAMSA 2019 Member List and Capability' Source of the IAMSA

Tabel 1.1 Types of Indonesian Aircraft Jet \& Tire of Indonesia's Airline ${ }^{[2]}$

\begin{tabular}{|c|c|c|c|c|c|c|}
\hline No & AIRCRAFT & $\begin{array}{l}\text { NUMBER OF } \\
\text { AIRCRAFT }\end{array}$ & $\begin{array}{c}\text { TIRE } \\
\text { POSITION }\end{array}$ & $\begin{array}{l}\text { NUMBER } \\
\text { OF TIRE }\end{array}$ & SPARE & $\begin{array}{c}\text { TOTAL } \\
\text { TIRE }\end{array}$ \\
\hline \multirow[t]{2}{*}{1} & B 777-300 & 4 & NLG & 8 & 2 & 10 \\
\hline & & & MLG & 32 & 6 & 38 \\
\hline \multirow[t]{2}{*}{2} & A $330-200$ & 8 & NLG & 16 & 3 & 19 \\
\hline & & & $\overline{M L G}$ & 64 & 12 & 76 \\
\hline \multirow[t]{4}{*}{3} & A 330-300 & 11 & NLG & 22 & 4 & 26 \\
\hline & & 23 & MLG & 88 & 18 & 106 \\
\hline & NLG NB* & Total 55 EA & ${ }^{*} \mathrm{NB}$ & & & \\
\hline & MLG NB & Total 216 EA & $\begin{array}{l}\text { Narrow } \\
\text { Body }\end{array}$ & & & \\
\hline \multirow[t]{2}{*}{4} & B 737-800 & 139 & NLG & 139 & $\overline{14}$ & 133 \\
\hline & & & MLG & 556 & 56 & 612 \\
\hline \multirow[t]{2}{*}{5} & B 737-900 & 75 & $\mathrm{NLG}$ & 75 & 8 & 83 \\
\hline & & & MLG & 300 & 30 & 330 \\
\hline \multirow[t]{2}{*}{6} & B 737-MAX8 & 9 & NLG & 9 & 1 & 10 \\
\hline & & & MLG & 36 & 4 & 40 \\
\hline \multirow[t]{4}{*}{7} & A 320-200 & 115 & NLG & 115 & 11 & 126 \\
\hline & & 338 & MLG & 460 & 46 & 506 \\
\hline & $\mathrm{NLG} \mathrm{WB}^{* *}$ & Total 352 EA & **WB : & & & \\
\hline & MLG WB & $\begin{array}{c}\text { Total } 1488 \\
\text { EA }\end{array}$ & Wide Body & & & \\
\hline
\end{tabular}

Table 1.2 List of IAMSA's Members 2019 and Its Capability

\section{IAMSA MEMBER's 2019}

\begin{tabular}{|c|l|l|}
\hline No & \multicolumn{1}{|c|}{ Nama } & \multicolumn{1}{|c|}{ Kategori } \\
\hline 1 & PT Aero Nusantara Indonesia & Engine \\
\hline 2 & PT Aero International Teknologi & Airframe \\
\hline 3 & PT Adhi Luhung Wicaksana & AEI \\
\hline 4 & PT Avtek Trans Utama & AEI \\
\hline 5 & PT Batam Aero Teknik & $\begin{array}{l}\text { Aiframe, } \\
\text { Engine }\end{array}$ \\
\hline 6 & PT Bandung Jet Aero & Airframe \\
\hline 7 & PT Bagas Nusantara Putra & AEI \\
\hline 8 & PT CMI Teknologi & AEI \\
\hline 9 & PT Dewata Angkasa & AEI \\
\hline 10 & PT Dwi Angkasa & AEI \\
\hline 11 & $\begin{array}{l}\text { Directorate Aircraft Services } \\
\text { (ACS) PT.DI }\end{array}$ & $\begin{array}{l}\text { Aiframe, } \\
\text { Engine }\end{array}$ \\
\hline 12 & PT Enggal Makmur Abadhi & Engine \\
\hline 13 & FL Technics Indonesia & Aiframe, \\
\hline 14 & PT Focus Angkasa Abadi & Airframe \\
\hline 15 & PT Fineks Utama & AEI \\
\hline & & \\
\hline
\end{tabular}

\begin{tabular}{|l|l|l|}
\hline No & \multicolumn{1}{|c|}{ Nama } & \multicolumn{1}{|c|}{ Kategori } \\
\hline 16 & PT GMF AeroAsia & Airframe, Engine, LM \\
\hline 17 & PT Indopelita Aircraft Services & Aiframe, Engine \\
\hline 18 & PT Indo Aero Semesta & AEI \\
\hline 19 & PT JAS Aero Engineering Services & Line Maintenance \\
\hline 20 & PT Kalimasada Pusaka & Airframe \\
\hline 21 & PT Kadomas Aviasindo & AEI \\
\hline 22 & PT Kandiyasa Dirgatama & AEI \\
\hline 23 & PT Maura Cipta Arta & Special Services \\
\hline 24 & PT MuladaTU & Special Services \\
\hline 25 & PT Merpati Maintenance Facility & Aiframe, Engine \\
\hline 26 & PT Nusantara Turbin dan Propulsi & Engine \\
\hline 27 & PT Putra Elang Angkasararaya & Aiframe, Engine \\
\hline 28 & PT Rekatama Putra Gegana & AEI \\
\hline 29 & PT Travira Air AMO & Aiframe, Engine \\
\hline 30 & PT Tribuana Aerospace & AEI \\
\hline 31 & PT Wira Jasa Angkasa & Airframe, AEI, SS \\
\hline
\end{tabular}


above, it appears that none of the MRO members of IAMSA in Indonesia have the capability or ability to retread tires. Meanwhile there is a need to retread tire of airline that operating in Indonesia, which is quite large, around USD 20 million per year. Currently retreads of aircraft tires owned by Indonesian airlines are carried out in Malaysia and Thailand [7].

\subsection{Objective}

The objective of this publication is to review how big is business opportunity to build aircraft tire retreading facilities in Indonesia.

\section{DISCUSSION}

\subsection{Methodology}

The methodology of this publication is a combination of literature studies, data collection and analysis from aviation industry publications, and data collection through interviews with MRO officers who are competent in retreading aircraft tires [2][6][7].

\subsection{Analysis}

There is a big business opportunity in tire retreading, around USD 20 Millions/year, according to MRO Officers. Dunlop will invest USD 70 Millions for this[7].

Several reasons why tire retreading has no capability yet at MRO Indonesia are :

1. The absence of full support from the government to force aircraft tire manufacturers (Goodyear / Goodrich / Bridgestone / Michelin) to be willing to work with MRO Indonesia to build a tire retread facility in Indonesia.

2. There is an unwillingness of aircraft tire retreading companies in Malaysia and Thailand which have been receiving aircraft tire retreading orders from Indonesia.

3. Most of business men only want to get big profits without investing in what they should.

4. Aircraft tire manufacturers are not interested in building aircraft tire factories in Indonesia due to the convoluted rules and licensing, inefficient supply chain and lack of attractive incentives provided by the government.

\subsection{Steps to seize opportunities}

The Steps needed in order to realize the facilities of aircraft tire retreading in Indonesia :

1. Conducting continuous campaigns to the government $\mathrm{cq}$ the Ministry of Industry and Ministry of Transportation to provide full support in the construction of aircraft tire retreading facilities in the country by providing an overview of business opportunities.

2. Incorporate an aircraft tire retreading facility development program into the National Strategic Program and into the Aerospace Industry Roadmap.

\section{CONCLUSIONS AND SUGGESTIONS}

\subsection{Conclusions}

The number of aircraft tires in Indonesia that are retread abroad for wide-body and narrow-body jets is very large, namely for wide-body jet airplanes for Nose Landing Gear/NLG and Main Landing Gear/MLG, respectively the number is 55 ea and 216 ea. For narrow body jets, each for NLG and MLG the number is 352 ea and 1488 ea. Where the total cost of retreading the tire is about USD 20 million per year and until now there are no facilities for retreading aircraft tires in Indonesia.

The cause of the lack of aircraft tire retreading facilities in Indonesia are due to the lack of government support, competition from facilities in Malysia and Thailand, lack of loyalty of domestic business players in investing, and also aircraft tire manufacturers less interested in building their factories in Indonesia.

The steps to be able to take the business opportunity to retread aircraft tires is to carry out a continuous campaign to the government to ask for support and to include an aircraft tire retreading facility 
development program in the National Strategic Program and into the Aerospace Industry Roadmap.

\subsection{Suggestions}

Large business opportunities in the airplane tire retreading industry in Indonesia, which is around USD 20 million per year, it is recommended to conduct further research on the feasibility and strategy of constructing aircraft tire retreading facility.

\section{ACKNOWLEDGMENTS}

This work was part of a research project funded by Unsurya and facilitated by IAMSA, under Memorandum of Agreement between Unsurya and IAMSA. kw

\section{REFERENCES}

1. SCRIBD, 'Aircraft Tire Care \& Maintenance' On The Wings of Good Year Aviation, Revised-10/04. Website : www.goodyearaviation.com

2. Indonesia National Air Carriers Association/INACA, 'Indonesia Aviation Outlook 2017'

3. DUNLOP AIRCRAFT TYRES, 'Retreading Airplane Tyres' , https://www.dunlopaircrafttyres.co.uk/tec hnical/retreading-process/

4. Market Research Future, 'Aircraft Tire Retreading Market Research Report: Information by Process (Pre-Cure and Mold-Cure), Aircraft Type (Commercial and Military), and Region (North America, Europe, Asia-Pacific, and the Rest of the World) - Global Forecast till 2023' ID: MRFR/A\&D/6125-HCR | July 2020

https://www.marketresearchfuture.com/r eports/aircraft-tire-retreading-market7594

5. Mordor Intelligence, 'AIRCRAFT TIRES MARKET - GROWTH, TRENDS, AND FORECAST (2020 - 2025), https://www.mordorintelligence.com/indu stry-reports/aircraft-tires- market

6. Ganet Dirgantara , 'BPPT Fasilitasi Industri Vulkanisir Ban Pesawat Terbang' Antara News, 27 November 2018. https://www.antaranews.com/berita/772 167/bppt-fasilitasi- industri-vulkanisirban-pesawat-terbang

7. Andi M Arief, 'Dunlop Kucurkan Rp 1 Triliun Bangun Pabrik Vulkanisir Ban Pesawat Terbang' Bisnis.com, 07 November 2019. https://ekonomi.bisnis.com/read/201911 07/257/1168116/dunlop-kucurkan-rp1triliun- bangun-pabrik-vulkanisir-banpesawat-terbang

8. Frost \& Sullivan, 'MRO 2025, Identifying Opportunities to Accelerate Growth', 2018

9. Adrian Schofield, 'Indonesia Emerges As One of Asia's MRO Hotspots', Oct 23 2017. 